\title{
Changes in the Mineral Composition of Rat Tissues Induced by Breast Cancer and Dietary Supplementation
}

\author{
DOROTA SKRAJNOWSKA, ANDRZEJ TOKARZ, \\ JUSTYNA MAKOWSKA and BARBARA BOBROWSKA-KORCZAK
}

Department of Bromatology, Medical University of Warsaw, Warsaw, Poland

\begin{abstract}
Background/Aim: The aim of the study was to determine the effect of various diets with zinc or zinc in combination with resveratrol or genistein on mineral contents of the serum, urine, liver, kidney and heart in rats with chemically-induced mammary carcinoma. Materials and Methods: The manuscript presents the tissues and body fluids content of iron, calcium, zinc, magnesium and copper in control rats or rats treated with 7,12-dimethyl-1,2benz[a]anthracene to induce mammary carcinogenesis, under four dietary conditions: standard feed, Zn supplemented feed (6.9 $\mathrm{mg} \mathrm{Zn/ml}), \mathrm{Zn}$ and resveratrol $(0.2 \mathrm{mg} / \mathrm{kg}$ body) supplemented feed, or $\mathrm{Zn}$ and genistein $(0.2 \mathrm{mg} / \mathrm{kg}$ body) supplemented feed. Results: The content of calcium and copper highly varied depending on the tissue and the type of dietary supplement (no change for zinc and magnesium). Irrespective of the diet used, the chemical induction of mammary cancer caused a decrease in iron concentration in most samples analysed. Only supplementation of the rats' diet with zinc and genistein induced no changes in iron distribution in the serum, urine, liver, kidney and heart. Conclusion: Further research using various levels of zinc and genistein in the diet should be conducted to determine how the development and progression of cancer is linked to iron content in cells and its ability to accumulate in tumour tissue.
\end{abstract}

Breast cancer is the most commonly occurring cancer in women and the second most common cancer overall. There were over 2 million new cases in 2018 (1). Patients facing cancer, in addition to various forms of treatment recommended

This article is freely accessible online.

Correspondence to: Barbara Bobrowska-Korczak, Department of Bromatology, Medical University of Warsaw, Poland, Banacha 1, 02-097 Warsaw, Poland. Tel/Fax: +48 225720785, e-mail: barbara.bobrowska@wum.edu.pl

Key Words: Breast cancer, zinc, genistein, resveratrol, bioelements, tissue samples. by their doctors, use a variety of dietary supplements to help their body fight the disease. Among minerals, these will undoubtedly include zinc (2-4) and selenium $(5,6)$ and among biologically active substances, polyphenolic compounds (including resveratrol and genistein) (7-9). Both in vitro studies on human cancer cells and in vivo studies on rodents have shown that zinc can inhibit the proliferation of certain types of tumour cells, while zinc deficiency increases cell proliferation and promotes inflammation $(10,11)$. Decreasing the serum levels of Se and $\mathrm{Zn}$ may be the risk factors for breast cancer (12). The role of zinc in the prevention of cancer is the result of antioxidant activity, which protects against DNA damage, and the complex effect of zinc on the immune system (induction of IL-1, IL-6, TNF-alpha, and monocytes, T cell differentiation; and others) $(10,11)$. Polyphenolic compounds exert an anti-carcinogenic effect not only through the immune system, but also by influencing the cell cycle, apoptosis, angiogenesis and metastasis $(7-9,13)$. Numerous studies have shown them to be promising agents in chemotherapy and other cancer treatments, alone $(14,15)$ or in combination with existing chemotherapeutics $(16,17)$. On the other hand, numerous studies have confirmed that tumour cells, due to their uncontrolled growth and chaotic division, require increased amounts of certain elements, which is manifested as changes in their content in the blood and as imbalances and altered proportions of the other elements in other tissues (18-20). Particular emphasis is placed on the effect of the tumour, exerted through various mechanisms, on iron metabolism (changes in gene expression, e.g. of ceruloplasmin, ferroportin, hepcidin, transferrin receptor proteins 1 and 2 (TfR1, TfR2), and iron regulatory proteins (IRP) $(21,22)$. Because macroand micronutrients play an important role in the proper functioning of the body, their imbalance may have a deeper effect in metabolic dysfunctions and tumour progression. Analysis of biochemical changes in the content of elements in the blood and organs could be a starting point in cancer epidemiology, first in early diagnosis and then in prognosis and in the support of treatment of cancer patients.

The study investigated the effect of dietary supplementation with zinc or zinc in combination with resveratrol or genistein 
on the content of iron and other elements $(\mathrm{Zn}, \mathrm{Ca}, \mathrm{Mg}$ and $\mathrm{Cu}$ ) in the serum, $24 \mathrm{~h}$ total urine, liver, kidney and heart of rats with chemically-induced mammary carcinoma.

\section{Materials and Methods}

Animals. Female Spraque-Dawley rats (30 days old) with a body weight of $100 \pm 20 \mathrm{~g}$ underwent a 10-day adaptation period. Then the study was conducted for 14 weeks (from 40 days to 20 weeks of age). The rats were individually housed in polypropylene cages and kept in a temperature and light-controlled environment. The rats were given free access to food (Labofeed $\mathrm{H}$; produced by Morawski, Kcynia, Poland) (23) and tap water. The rats were obtained from the Laboratory of Experimental Animals, Department of General and Experimental Pathology, Medical University of Warsaw (Warsaw, Poland). The animal experiments were approved by the Ethics Committee of the Medical University of Warsaw.

Animal groups and diets. The rats were initially divided into a cancer group $(n=32)$ and a control group $(n=24)$. To induce mammary tumorigenesis, the rats from the cancer group were administered DMBA (7,12-dimethyl-1,2-benz[a]anthracene; SigmaAldrich, St. Louis, MO, USA) by gavage in rapeseed oil at a dose of $80 \mathrm{mg} / \mathrm{kg}$ body weight at 50 and 80 days of age. Histopathological evaluation of the tumors was performed to confirm their malignancy and verify that they were adenocarcinomas (grades 2 and 3). The control group comprised rats kept in the same conditions and fed the same diet as the rats from the cancer group, but not treated with DMBA. Spontaneous cancers were not found in the non-DMBA groups (24).

Each group (except the animals receiving no supplements, i.e.the Standard group) received intragastrically one of three $\mathrm{Zn}$ compounds, so that the following groups were distinguished:

Zinc group $(\mathrm{Zn})$ : animals received a daily supplement of $0.4 \mathrm{ml}$ of $\mathrm{Zn}\left(6.9 \mathrm{mg} / \mathrm{ml}\right.$; i.e. $231 \mathrm{mg} \mathrm{Zn} / \mathrm{kg}$ diet) (as $\mathrm{ZnSO}_{4} \cdot 7 \mathrm{H}_{2} \mathrm{O}$ in aqueous suspension, POCH S.A. Gliwice, Poland) (both cancer group and control group).

Zinc and resveratrol group (ZnR): animalsreceived a daily supplement of $0.4 \mathrm{ml}$ of $\mathrm{Zn}(6.9 \mathrm{mg} / \mathrm{ml})$ and resveratrol $(3,4,5$-Trihydroxy-transstilbene, Sigma-Aldrich) $(0.1 \mathrm{mg} / \mathrm{ml}$; i.e. $0.2 \mathrm{mg} / \mathrm{kg} . \mathrm{bw})$ in aqueous suspension (both cancer group and control group).

Zinc and genistein group $(\mathrm{ZnG})$ : animals received a daily supplement of $0.4 \mathrm{ml}$ of $\mathrm{Zn}(6.9 \mathrm{mg} / \mathrm{ml})$ and genistein (4'5,7-Trihydroxyisoflavone) (Sigma-Aldrich) $(0.1 \mathrm{mg} / \mathrm{ml}$; i.e. $0.2 \mathrm{mg} / \mathrm{kg} . \mathrm{bw})$ in aqueous suspension (both cancer group and control group).

Standard group $(S)$ : animals received a daily of $0.4 \mathrm{ml}$ of water with no supplements (both cancer group and control group).

The dose of $\mathrm{Zn}$ was based on the value used in the standard diet, i.e. the Labofeed H diet (Kcynia, Poland) (23), which contained 77 $\mathrm{mg} \mathrm{Zn/kg} \mathrm{diet.} \mathrm{The} \mathrm{Zn}$ dose was three times higher than the amount of $\mathrm{Zn}$ in the feed. The polyphenols dose was based on average human daily intake (extrapolated to the rats' body weight). The cancer and control group each comprised 6-8 rats. This report is a supplementary analysis of a study whose results have previously been published $(24,25)$.
Sample collection and preparation. At 20 weeks of age, the rats were weighed and housed ( $24 \mathrm{~h}$ ) in metabolic cages for urine collection. Animals were sacrificed by decapitation at week 20 after an overnight fast in the metabolic cages. The liver, kidney and heart were removed from the adhering connective tissue and precisely weighed. The tissues and $24 \mathrm{~h}$ urine were stored at $-80^{\circ} \mathrm{C}$ until testing. The mineral content was determined following wet microwave mineralization of the samples (heart, kidney and $0.5 \mathrm{~g}$ of liver). Samples of tissues and urine $(3 \mathrm{ml})$ were placed in a Teflon vessel with $3.5 \mathrm{ml}$ of $65 \%$ nitric acid (Suprapur ${ }^{\circledR}$, Merck, Germany). The vessels were placed in a microwave system (Plazmatronica, Wroclaw, Poland) and their contents were mineralized. After decomposition, the samples were transferred to a $10 \mathrm{ml}$ volumetric flask and filled to volume with double-distilled water. The flame atomic absorption spectrometry (FAAS) technique (PUnicam, 9100, Cambridge, UK) was used to analyze the following elements: zinc $(\mathrm{Zn})$, calcium $(\mathrm{Ca})$, magnesium $(\mathrm{Mg})$, iron $(\mathrm{Fe})$ and copper $(\mathrm{Cu})$. The analysis was carried out using a PUnicam 9100 atomic absorption spectrometer, in an oxidizing air-acetylene flame at wavelengths of 213.9 for $\mathrm{Zn}, 324.7$ for $\mathrm{Cu}, 248.3$ for $\mathrm{Fe}$, 422.7 for $\mathrm{Ca}$ and $285.3 \mathrm{~nm}$ for $\mathrm{Mg}$. Hollow-cathode lamps (PerkinElmer) were used as radiation source. For the determination of minerals ( $\mathrm{Fe}, \mathrm{Ca}$ and $\mathrm{Mg}$ ), $0.5 \mathrm{ml}$ samples of tissues and urine were diluted with deionized water at 1:10 for $\mathrm{Fe}$ and 1:25 for $\mathrm{Ca}$ and $\mathrm{Mg}$. Standard solutions of $\mathrm{Ca}, \mathrm{Mg}, \mathrm{Fe}, \mathrm{Zn}$ and $\mathrm{Cu}$ were prepared from their standard solutions (1000 mg/l in water) from the Central Office of Measures, Warsaw, Poland).

Blood collection and preparation. The serum samples were stored in a deep freezer at $-80^{\circ} \mathrm{C}$ until analysis. Before the determinations the serum was thawed and then centrifuged at $3000 \mathrm{rpm}$ for $10 \mathrm{~min}$ $\mathrm{Zn}, \mathrm{Ca}, \mathrm{Mg}, \mathrm{Fe}$ and $\mathrm{Cu}$ were determined in serum samples by airacetylene flame atomic absorption spectrometry (PU-9100). For determination of minerals, $0.5 \mathrm{ml}$ serum samples were diluted with deionized water at 1:10 for $\mathrm{Zn}, \mathrm{Fe}, \mathrm{Cu}$ and 1:70 for $\mathrm{Ca}$ and $\mathrm{Mg}$. Standard solutions of $\mathrm{Zn}, \mathrm{Ca}, \mathrm{Mg}, \mathrm{Fe}$ and $\mathrm{Cu}$ were prepared from their standard solutions $(1,000 \mathrm{mg} / \mathrm{l}$ in water) from Central Office of Measures, Warsaw, Poland).

Recovery and detection limit. The intralaboratory quality control of determination was done using the following certified Reference Materials (percent of recovery for a given element).

NCS ZC 71001 Beef Liver recoveries: Zn: 110\%; Ca: 90\%; Mg: 103\%; Fe: $106 \%$; $\mathrm{Cu}: 95 \%$.

Seronorm Trace Elements Serum -1 (SERO201405) recoveries: Zn: $101 \%$; Ca: $90 \%$; Mg: 96\%; Fe: $100 \%$; Cu: $106 \%$.

The limits of detection, calculated as concentrations corresponding with an absorption value equal to a three-fold standard deviation of the signal for the lowest standard

Limits of detection (LOD) for: $\mathrm{Zn}: 0.1 \mathrm{mg} / \mathrm{l} ; \mathrm{Ca}: 0.2 \mathrm{mg} / \mathrm{l} ; \mathrm{Mg}$ : $0.03 \mathrm{mg} / \mathrm{l}$; Fe: $0.3 \mathrm{mg} / \mathrm{l} ; \mathrm{Cu}: 0.1 \mathrm{mg} / \mathrm{l}$.

Statistical analysis. Results were expressed as mean and standard deviation. The Statistica 12.0 software (StatSoft, Tulsa, OK, USA) was used for statistical analysis. The normal distribution of the data was tested using the Shapiro-Wilk method. For the normal data, the Student's test and ANOVA, followed by Tukey's test with unequal sample size were used for analysis. The non-normal data was analyzed with Mann-Whitney $U$ non-parametric test. The results were considered statistically significant when $p \leq 0.05$. 
Skrajnowska et al: Mineral Tissues Composition, Zinc, Polyphenols and Breast Cancer

Table I. Statistical distribution parameters for trace element concentrations in the serum, 24 h urine, heart, liver and kidney of breast cancer and control rats received the standard diet and the supplemented diets.

\begin{tabular}{|c|c|c|c|c|c|c|c|c|c|}
\hline \multirow{2}{*}{$\begin{array}{l}\text { Diets } \rightarrow \\
\text { Tissues } \\
\downarrow\end{array}$} & \multirow{2}{*}{$\begin{array}{c}\text { Element } \\
\downarrow\end{array}$} & \multicolumn{2}{|c|}{ Standard (S) } & \multicolumn{2}{|c|}{ Zinc $(\mathrm{Zn})$} & \multicolumn{2}{|c|}{ Zinc and resveratrol $(\mathrm{ZnR})$} & \multicolumn{2}{|c|}{ Zinc and genistein $(\mathrm{ZnG})$} \\
\hline & & $\begin{array}{c}\text { Cancer } \\
\text { mean } \pm \text { SD }\end{array}$ & $\begin{array}{c}\text { Control } \\
\text { mean } \pm \text { SD }\end{array}$ & $\begin{array}{c}\text { Cancer } \\
\text { mean } \pm \text { SD }\end{array}$ & $\begin{array}{c}\text { Control } \\
\text { mean } \pm \text { SD }\end{array}$ & $\begin{array}{c}\text { Cancer } \\
\text { mean } \pm \text { SD }\end{array}$ & $\begin{array}{c}\text { Control } \\
\text { mean } \pm \text { SD }\end{array}$ & $\begin{array}{c}\text { Cancer } \\
\text { mean } \pm \text { SD }\end{array}$ & $\begin{array}{c}\text { Control } \\
\text { mean } \pm \text { SD }\end{array}$ \\
\hline \multirow{5}{*}{$\begin{array}{l}\text { Serum } \\
(\mu \mathrm{g} / \mathrm{ml})\end{array}$} & $\mathrm{Zn}$ & $1.25 \pm 0.10$ & $1.40 \pm 0.15$ & $1.20 \pm 0.07$ & $1.23 \pm$ & $1.32 \pm 0.22$ & $1.40 \pm$ & $1.10 \pm 0.10$ & $1.1 \mathrm{C}$ \\
\hline & $\mathrm{Ca}$ & $92.17 \pm 11.13$ & $87.63 \pm 1.74 *$ & $101.6 \pm 11.61$ & $92.01 \pm 8.39$ & $102.8 \pm 6.57$ & $87.63 \pm 1.74 *$ & $104.9 \pm 15.26$ & $89.73 \pm 6.91$ \\
\hline & $\mathrm{Mg}$ & $19.22 \pm 1.29$ & $18.60 \pm 1.09$ & $17.66 \pm 1.44$ & $18.06 \pm 1.57$ & $18.99 \pm 1.50$ & $18.60 \pm 1.09$ & $17.59 \pm 1.53$ & $18.62 \pm 1.59$ \\
\hline & $\mathrm{Fe}$ & $2.86 \pm 0.53$ & $4.31 \pm 0.57 *$ & $3.12 \pm 1.02$ & $5.47 \pm 0.81 *$ & & & & \\
\hline & $\mathrm{Cu}$ & $0.80 \pm 0$ & $1.74 \pm 0$ & $1.38 \pm 0$ & $1.79 \pm$ & $1.47 \pm($ & 1.74 & $1.27 \pm$ & \\
\hline \multirow{5}{*}{$\begin{array}{l}24 \mathrm{~h} \text { urine } \\
(\mu \mathrm{g})\end{array}$} & $\mathrm{Zn}$ & $15.42 \pm 6.70$ & $33.13 \pm 1^{\prime}$ & $18.96 \pm 7.02$ & $15.42 \pm 5$ & $11.03 \pm 7.32$ & & & $25.34 \pm 6.481$ \\
\hline & $\mathrm{Ca}$ & $103.1 \pm 60.3$ & $338.4+$ & 200556 & & & & & \\
\hline & $\mathrm{Mg}$ & & & & & & & & \\
\hline & $\mathrm{Fe}$ & & & & & & & & \\
\hline & $\mathrm{Cu}$ & $2.226 \pm 1.6$ & 3.497 & $2.422 \pm 1$. & & 1.264 & 3.497 & & \\
\hline \multirow{5}{*}{$\begin{array}{l}\text { Heart } \\
(\mu \mathrm{g} / \mathrm{g})\end{array}$} & $\mathrm{Zn}$ & $21.38 \pm 0.587$ & $20.12 \pm 0.412$ & $21.14 \pm 1.61$ & $19.82 \pm 0.616$ & $20.59 \pm 0.884$ & 20.12 & 19.56 & 0.732 \\
\hline & $\mathrm{Ca}$ & $34.92 \pm 11.67$ & 40.1 & $42.23 \pm 7.24$ & 33.16 & 41.64 & 40.1 & 48.04 & 5.09 \\
\hline & $\mathrm{Mg}$ & $146.6 \pm 8.30$ & $143.6=$ & $141.6 \pm 7.80$ & 143.9 & $138.5=$ & 143.6 & 138.1 & $6.89^{*}$ \\
\hline & $\mathrm{Fe}$ & $63.93 \pm 8.214$ & $73.36 \pm 7.486^{*}$ & $67.59 \pm 11.77$ & $69.39 \pm 6.96$ & $58.89 \pm 7.12$ & $73.36 \pm 7.486^{*}$ & 7.352 & 70.98 \\
\hline & $\mathrm{Cu}$ & $4.486 \pm 0.10$ & $4.387 \pm 0.205$ & $4.423 \pm 0.262$ & $3.941=$ & $4.489 \pm 0.206$ & $4.387 \pm 0.205$ & $4.085 \pm 0.127$ & 4.354 \\
\hline \multirow{5}{*}{$\begin{array}{l}\text { Liver } \\
(\mu \mathrm{g} / \mathrm{g})\end{array}$} & $\mathrm{Zn}$ & $41.0 \pm 4.85$ & $38.89 \pm 3.204$ & $39.04 \pm 0.61$ & $41.26 \pm 3.062$ & $35.84 \pm 4.02$ & $38.89 \pm 3.204$ & $40.22 \pm 3.67$ & $39.50 \pm 4.861$ \\
\hline & $\mathrm{Ca}$ & $35.54 \pm 7.04$ & $27.53 \pm 5.03 *$ & $31.25 \pm 2.15$ & $23.71 \pm 8.33 *$ & $20.86 \pm 5.311$ & $27.53 \pm 5.03 *$ & $40.38 \pm 12.25$ & $17.71 \pm 4.65^{*}$ \\
\hline & $\mathrm{Mg}$ & $223.4 \pm 15.1$ & $223.7 \pm 10.3$ & $218.8 \pm 6.22$ & $225.4 \pm 8.71$ & $221.1 \pm 10.0$ & $223.7 \pm 10.3$ & $237.6 \pm 10.6$ & $228.9 \pm 8.62$ \\
\hline & $\mathrm{Fe}$ & $384.2 \pm 57.8$ & $565.6 \pm 47.92 *$ & $445.0 \pm 88.4$ & $545.3 \pm 21.5^{*}$ & $343.4 \pm 140.0$ & $565.6 \pm 47.92 *$ & $482.6 \pm 87.1$ & $532.1 \pm 65.5$ \\
\hline & $\mathrm{Cu}$ & $4.923 \pm 0.462$ & $5.726 \pm 0.952 *$ & $4.851 \pm 0.408$ & $5.239 \pm 0.529$ & $4.453 \pm 0.743$ & $5.726 \pm 0.952 *$ & $5.348 \pm 0.853$ & $4.483 \pm 0.453 *$ \\
\hline \multirow{5}{*}{$\begin{array}{l}\text { Kidney } \\
(\mu \mathrm{g} / \mathrm{g})\end{array}$} & $\mathrm{Zn}$ & $32.33 \pm 2.79$ & $30.96 \pm 0.79$ & $31.78 \pm 2.56$ & $30.33 \pm 2.01$ & $32.68 \pm 2.78$ & $30.96 \pm 0.79$ & $31.72 \pm 1.47$ & $30.38 \pm 1.26$ \\
\hline & $\mathrm{Ca}$ & $100.0 \pm 62.6$ & $161.1 \pm 81.1^{*}$ & $49.8 \pm 15,88$ & $73.29 \pm 24.66$ & $35.03 \pm 11,49$ & $161.1 \pm 81.1^{*}$ & $370.7 \pm 214,9$ & $198.4 \pm 61.1$ \\
\hline & $\mathrm{Mg}$ & $167.8 \pm 5.63$ & $173.3 \pm 4.71$ & $164.3 \pm 10.54$ & $164.9 \pm 3.788$ & $169.3 \pm 13.51$ & $173.3 \pm 4.71$ & $176.4 \pm 4.183$ & $169.8 \pm 6.047 *$ \\
\hline & $\mathrm{Fe}$ & $82.37 \pm 12.6$ & $88.98 \pm 8.39$ & $80.87 \pm 13.93$ & $84.37 \pm 8.99$ & $95.16 \pm 17.86$ & $88.98 \pm 8.39$ & $91.78 \pm 15.99$ & $92.86 \pm 9.79$ \\
\hline & $\mathrm{Cu}$ & $6.079 \pm 0.928$ & $7.164 \pm 0.903$ & $7.82 \pm 1.709$ & $6.133 \pm 0.829 *$ & $7.932 \pm 1.401$ & $7.164 \pm 0.903$ & $5.717 \pm 1.753$ & $6.172 \pm 1.262$ \\
\hline
\end{tabular}

S: Standard diet, Zn: zinc diet, ZnR: zinc and resveratrol diet, ZnG: zinc and genistein diet; SD: Standard deviation. *differences in the minerals between the cancer group and the control group, fed the same diet, for the significance level $p \leq 0.05$.

\section{Results}

Basic statistical distribution parameters (means, standard deviation) of the trace elements in the serum, 24-h urine, heart, liver and kidney of the cancer and control rats receiving the diets are depicted in Table I.

Table II presents the weight of the hearts, livers and kidneys of rats from the cancer and control groups fed a standard diet and after 100-day supplementation with zinc and zinc in combination with resveratrol or genistein. A significant increase in liver weight was noted in the groups receiving zinc and zinc with resveratrol (by $42 \%$ and $18 \%$, respectively) compared to the control groups receiving the same supplements. No changes were noted in the weight of the organs (liver, heart and kidney) in the groups whose diet was supplemented with zinc and genistein (Table II).

Table III shows direction and percentage of changes in the content of $\mathrm{Zn}, \mathrm{Ca}, \mathrm{Mg}, \mathrm{Fe}$ and $\mathrm{Cu}$ in the fluids and tissues of rats with cancer receiving a standard diet (without supplements); diet supplemented with zinc; diet supplemented with zinc and resveratrol and diet supplemented with zinc and genistein compared to the control group on the same diet. In the rats fed only the standard diet, the neoplastic process significantly reduced the iron content in most of the tissues tested. It is also worth noting the significant reduction in urinary excretion of zinc, calcium, magnesium and iron in comparison to the control (Table III). Dietary supplementation with zinc produced no statistically significant changes in the excretion of the elements in the urine compared to the control. In this case as well, the level of iron in the serum and liver was reduced in the rats with mammary cancer. The content of calcium in the liver and of copper in the kidneys also significantly increased (Table III).

Zinc and resveratrol supplementation of the diet of rats with induced mammary carcinoma caused the most changes in the content of the elements in the tissues. As in the case of the diets discussed above, there was a significant reduction in the content of iron, but also of copper and calcium (apart from the serum). For the first time, a small but significant decrease in magnesium content was noted in the heart, as well as strong inhibition of zinc and copper 
Table II. A comparison of the differences between the mass of heart, liver and kidney of the rats from the cancer group and the control group received the same diet.

\begin{tabular}{lccc}
\hline $\begin{array}{l}\text { Diets } \\
\downarrow\end{array}$ & $\begin{array}{c}\text { Mass of } \\
\text { heart } \\
(\bar{X} \pm S D)\end{array}$ & $\begin{array}{c}\text { Mass of } \\
\text { liver } \\
(\bar{X} \pm S D)\end{array}$ & $\begin{array}{c}\text { Mass of } \\
\text { kidney } \\
(\bar{X} \pm S D)\end{array}$ \\
\hline $\begin{array}{l}\text { Standard diet } \\
\text { Cancer (n=8) }\end{array}$ & $0.83 \pm 0.08$ & $6.992 \pm 0.782$ & $1.633 \pm 0.14^{*}$ \\
$\quad$ Control (n=6) & $0.923 \pm 0.09$ & $6.468 \pm 0.891$ & $1.965 \pm 0.13$ \\
Zinc diet & & & \\
$\quad$ Cancer (n=8) & $0.937 \pm 0.16$ & $7.686 \pm 1.209^{*}$ & $1.698 \pm 0.11$ \\
$\quad$ Control (n=6) & $0.827 \pm 0.13$ & $5.408 \pm 0.869$ & $1.677 \pm 0.18$ \\
$\begin{array}{c}\text { Zinc and resveratrol diet } \\
\text { Cancer (n=8) }\end{array}$ & $0.878 \pm 0.1 *$ & $7.633 \pm 0.758^{*}$ & $1.688 \pm 0.30$ \\
$\quad$ Control (n=6) & $0.686 \pm 0.06$ & $6.484 \pm 0.50$ & $1.713 \pm 0.08$ \\
$\begin{array}{c}\text { Zinc and genistein diet } \\
\text { Cancer (n=8) }\end{array}$ & $0.798 \pm 0.13$ & $5.991 \pm 1.04$ & $1.587 \pm 0.24$ \\
Control (n=6) & $0.895 \pm 0.11$ & $6.033 \pm 0.579$ & $1.74 \pm 0.29$ \\
\hline
\end{tabular}

*Differences in the mass of organs between the cancer group and the control group, fed the same diet, for the significance level $p \leq 0.05$. $\mathrm{n}$ : Number of rats; : arithmetic mean; SD: standard deviation.

excretion in the urine. A more than $20 \%$ reduction in calcium and copper concentrations in the liver was observed compared to the control (Table III). In contrast to the other diets, supplementation with zinc and genistein did not alter the iron content in any of the tissues tested. In the heart of the rats with cancer a slight decrease was noted in the level of magnesium (as in the case of the zinc and resveratrol diet) and copper compared to the control. It is interesting to note that the mineral concentrations in the serum and urine were similar $(p>0.05)$ in the cancer and control rats.

Multivariate analysis of variance (Table IV) showed that the effect of chemically-induced mammary carcinoma on the content of elements was found mainly for iron and calcium. The iron concentration decreased in nearly all tissues (in the heart, liver, serum and $24 \mathrm{~h}$ urine) of the rats with mammary carcinoma as compared to the control rats. The calcium concentration increased in the heart, liver and serum (Table IV).

Analysis of the second factor, i.e. the diet used (Table IV), on the content of minerals in the tissues revealed a slight effect on the concentrations of iron and zinc and a strong effect on the content of magnesium (in the $24 \mathrm{~h}$ urine and liver), calcium (in the kidneys) and copper in the serum.

\section{Discussion}

Zinc, is often considered to be relatively nontoxic, however, dietary zinc concentrations in excess of $250 \mathrm{mg} / \mathrm{kg}$ can induce a copper deficiency if dietary copper is low or marginal (26). Zinc at a dose of over $5,000 \mathrm{mg} / \mathrm{kg}$ of diet induces inhibition of growth in rats, anorexia, anaemia, and even death,
Table III. Direction and percentage of changes in the content of zinc $(\mathrm{Zn})$, calcium $(\mathrm{Ca})$, magnesium $(\mathrm{Mg})$, iron $(\mathrm{Fe})$ and copper $(\mathrm{Cu})$ in the fluids and tissues of rats with cancer receiving various diets as compared to the control group on the same diet (based on data from Table I).

\begin{tabular}{|c|c|c|c|c|c|}
\hline & $\mathrm{Zn}$ & $\mathrm{Ca}$ & $\mathrm{Mg}$ & $\mathrm{Fe}$ & $\mathrm{Cu}$ \\
\hline \multicolumn{6}{|c|}{ Standard diet } \\
\hline Serum & - & $\uparrow 18 \%$ & - & $\downarrow 41 \%$ & - \\
\hline $24 \mathrm{~h}$ urine & $\downarrow 49 \%$ & $\downarrow 61 \%$ & $\downarrow 56 \%$ & $\downarrow 70 \%$ & \\
\hline Heart & - & - & - & - & $\downarrow 5 \%$ \\
\hline Liver & - & - & - & $\downarrow 28 \%$ & - \\
\hline Kidney & - & - & - & - & - \\
\hline \multicolumn{6}{|l|}{$\mathrm{Zn}$ diet } \\
\hline Serum & - & - & - & $\downarrow 43 \%$ & - \\
\hline $24 \mathrm{~h}$ urine & - & - & - & - & - \\
\hline Heart & - & - & - & - & - \\
\hline Liver & - & $\uparrow 32 \%$ & - & $\downarrow 18 \%$ & - \\
\hline Kidney & - & - & - & - & $\uparrow 28 \%$ \\
\hline \multicolumn{6}{|c|}{$\begin{array}{l}\mathrm{Zn} \text { and reswe- } \\
\text { ratrol diet }\end{array}$} \\
\hline Serum & - & $\uparrow 17 \%$ & - & $\downarrow 45 \%$ & - \\
\hline $24 \mathrm{~h}$ urine & $\downarrow 67 \%$ & - & - & - & $\downarrow 64 \%$ \\
\hline Heart & - & - & $\downarrow 4 \%$ & $\downarrow 20 \%$ & - \\
\hline Liver & - & $\downarrow 24 \%$ & - & $\downarrow 39 \%$ & $\downarrow 22 \%$ \\
\hline Kidney & - & $\downarrow 78 \%$ & - & - & - \\
\hline \multicolumn{6}{|c|}{$\begin{array}{l}\mathrm{Zn} \text { and } \\
\text { genistein diet }\end{array}$} \\
\hline Serum & - & - & - & - & - \\
\hline $24 \mathrm{~h}$ urine & - & - & - & - & - \\
\hline Heart & - & - & $\downarrow 9 \%$ & - & $\downarrow 6 \%$ \\
\hline Liver & - & $\uparrow 28 \%$ & - & - & $\uparrow 19 \%$ \\
\hline Kidney & - & - & $\uparrow 4 \%$ & - & - \\
\hline
\end{tabular}

$\downarrow$ : Statistically significant decrease; $\uparrow:$ statistically significant increase; '-': non-statistically significant.

irrespective of the level of copper in the diet. In our in vivo study, the dosage of zinc applied ( $237 \mathrm{mg} / \mathrm{kg}$ of diet) was three times higher than the amount normally found in feed (77 $\mathrm{mg} / \mathrm{kg}$ ). Despite this, no changes in the content of this element were observed in the organs tested, i.e. the heart, liver or in the serum. However, multivariate analysis revealed significant differences in zinc content in the urine and kidneys of the rats depending on the presence of mammary carcinoma, while there were no differences at all in the level of this element depending on the diet. Furthermore, no significant interactions were noted when the effect of cancer and that of diet on the zinc concentration in the tissues (kidney and serum) were compared simultaneously. The main route of zinc removal from the body is excretion in the faeces, while the level of urinary excretion is very low. The amount of zinc administered was probably effectively eliminated as a result of adaptation processes. On the other hand, an excess of absorbed zinc is mainly deposited 
Table IV. Results of multivariate analysis of variance and post hoc tests: effect of factors 'cancer' and 'diet' on the content of elements in tissues.

\begin{tabular}{|c|c|c|c|c|c|c|c|c|}
\hline \multirow{2}{*}{ Tissues } & \multirow{2}{*}{ Elements } & \multirow{2}{*}{$\begin{array}{l}\text { Main factor } \\
\text { cancer } \\
(p)\end{array}$} & \multicolumn{6}{|c|}{ Main factor diets } \\
\hline & & & Standard:Zn & Standard:ZnR & Standard:ZnG & $\mathrm{Zn}: \mathrm{ZnR}$ & $\mathrm{Zn}: \mathrm{ZnG}$ & $\mathrm{ZnR}: \mathrm{ZnG}$ \\
\hline \multirow{5}{*}{$\begin{array}{l}\text { Serum } \\
(\mu \mathrm{g} / \mathrm{ml})\end{array}$} & $\mathrm{Zn}$ & - & - & - & - & - & - & - \\
\hline & $\mathrm{Ca}$ & 0.000245 & - & - & 0.021245 & - & - & - \\
\hline & $\mathrm{Mg}$ & - & - & - & - & - & - & - \\
\hline & $\mathrm{Fe}$ & 0.001170 & - & - & - & 0.004785 & 0.015648 & - \\
\hline & $\mathrm{Cu}$ & - & 0.000171 & 0.000171 & 0.001453 & - & 0.037990 & 0.037915 \\
\hline \multirow{5}{*}{$\begin{array}{l}\text { 24h Urine } \\
(\mu \mathrm{g} /)\end{array}$} & $\mathrm{Zn}$ & 0.000418 & - & - & - & - & - & - \\
\hline & $\mathrm{Ca}$ & - & 0.044742 & - & - & - & - & - \\
\hline & $\mathrm{Mg}$ & - & 0.000420 & - & - & 0.000172 & 0.000168 & - \\
\hline & $\mathrm{Fe}$ & 0.001185 & - & - & - & - & - & - \\
\hline & $\mathrm{Cu}$ & 0.023342 & - & - & - & - & - & - \\
\hline \multirow{5}{*}{$\begin{array}{l}\text { Heart } \\
(\mu \mathrm{g} / \mathrm{g})\end{array}$} & $\mathrm{Zn}$ & - & - & - & 0.002223 & - & - & - \\
\hline & $\mathrm{Ca}$ & 0.039559 & - & - & - & - & - & - \\
\hline & $\mathrm{Mg}$ & 0.000718 & - & 0.016991 & - & - & - & - \\
\hline & $\mathrm{Fe}$ & 0.005597 & - & - & - & - & - & - \\
\hline & $\mathrm{Cu}$ & - & - & - & 0.030933 & - & - & - \\
\hline \multirow{5}{*}{$\begin{array}{l}\text { Liver } \\
(\mu \mathrm{g} / \mathrm{g})\end{array}$} & $\mathrm{Zn}$ & - & - & 0.004335 & - & - & - & - \\
\hline & $\mathrm{Ca}$ & 0.000825 & - & 0.001686 & - & - & - & 0.030142 \\
\hline & $\mathrm{Mg}$ & - & - & - & 0.018979 & - & 0.006844 & 0.010857 \\
\hline & $\mathrm{Fe}$ & 0.000116 & - & - & - & - & - & - \\
\hline & $\mathrm{Cu}$ & - & - & - & - & - & - & - \\
\hline \multirow{5}{*}{$\begin{array}{l}\text { Kidney } \\
(\mu \mathrm{g} / \mathrm{g})\end{array}$} & $\mathrm{Zn}$ & 0.009779 & - & - & - & - & - & - \\
\hline & $\mathrm{Ca}$ & - & - & - & 0.002519 & - & 0.000202 & 0.001280 \\
\hline & $\mathrm{Mg}$ & - & - & - & - & - & - & - \\
\hline & $\mathrm{Fe}$ & - & - & - & - & - & - & - \\
\hline & $\mathrm{Cu}$ & - & - & - & - & - & - & 0.007636 \\
\hline
\end{tabular}

'-': Non-significant; Zn: zinc diet, ZnR: zinc and resveratrol diet, ZnG: zinc and genistein diet, $p \leq 0.05$.

in the bones $(27,28)$. Moreover, the mineral excretion in urine was not correlated with dietary intake in this study. It should be stressed that the dosage of zinc applied was not toxic to the rats but could have had an immunosuppressive effect. The degree to which zinc and polyphenol supplementation in the research model influenced the neoplastic process was described in detail in our previous work (24). In that study, DMBA induced tumours in all rats irrespective of the diet used, but the tumours appeared at different times and in different numbers. The group supplemented with zinc and resveratrol was characterized by a maximal number of 10 tumors per rat. In this group the first tumors appeared at 13 weeks of age, i.e. two weeks earlier than in the groups receiving zinc or zinc with genistein or only the standard diet (24). It can, thus, be concluded that the dietary supplementation with zinc or a combination of zinc and polyphenols did not have a protective effect, and the combination of zinc and resveratrol even accelerated the appearance of tumours.

Zhang et al. (29) studied the effect of the interaction between zinc and resveratrol on normal human prostate epithelial cells (NHPrE) cells, which physiologically accumulate 10 times more zinc than other organs, such as the liver or kidneys. They found that inhibition of proliferation of NHPrE cells treated with resveratrol may be linked to an increase in the total cellular zinc concentration. Under normal conditions, zinc uptake and transport to and from the cell is carried out by its transporters (30). However, in conditions of additional supply of resveratrol, other channels may be activated by resveratrol, allowing extracellular zinc to be introduced by this route. Resveratrol is known to form complexes with $\mathrm{Cu}$ (II), which is followed by reduction of copper ions and formation of ROS. The similarity between the atomic structures of zinc and copper suggests that resveratrol can chelate zinc, which passes through cell membranes via channels specific for resveratrol (29).

According to the results obtained by Zhang et al. (29), resveratrol can therefore increase both the total zinc content and the biologically active pool in the cell, but this favourable phenomenon affects prostate cells, for which zinc is extremely important. In our research model, in conditions of chronic mammary carcinoma with multiple tumours, the administration of zinc with resveratrol led to substantial changes in the distribution of the other elements tested and also stimulated carcinogenesis (24). This seems to be linked 
to an excess of intracellular ROS and an immunosuppressive effect induced by an excess of zinc.

The chronic neoplastic process in the mammary gland had little effect on the weight of the heart and kidney. However, in the groups whose diet was supplemented with zinc or with zinc and resveratrol, increased liver weight was observed in the rats with cancer. Our previous research (25) showed an enormous increase, of $80 \%$ on average, in the weight of the spleen, together with a strong reduction in its iron concentration (29$58 \%$ ), in all groups except the group receiving zinc and genistein, which we believe is mainly indicative of the effect of iron deficiency on the immune system (31).

In the present study, characteristic changes in the distribution of elements were most frequently observed in the case of iron. Three of the four diets used (all but the diet supplemented with zinc and genistein) were shown to significantly reduce the concentration of this element in the body fluids and tissues. The iron concentration decreased significantly by more than $40 \%$ in the serum as compared to the rats without chemically-induced mammary cancer (although only about $0.1 \%$ of the total iron in the body is found in the plasma together with transferrin, which transfers it to the cells) $(32,33)$. Single statistically significant changes were also noted in the heart and kidneys ( $\mathrm{Zn}$ plus resveratrol group and Standard group). Excessive zinc consumption is known to affect iron metabolism as a result of interaction with ligands in the intestinal lumen. However, in our research model, the iron concentration also decreased in the case of correct zinc intake (Standard group).

In our previous studies (24) we found that mammary tumor cells were characterized by an increase in iron content by $28 \%$ $55 \%$ as compared with the amount of iron in healthy breast tissue (irrespectively of the diet applied). The present study demonstrated a reduction in iron content in another storage site of this element, i.e. the liver of the rats with induced mammary cancer (18-39\%). Iron accumulates in various tissues, but its main storage sites are the bone marrow, liver and spleen (primarily bound with ferritin and hemosiderin) $(32,33)$.

Hence the study confirms the occurrence of severe disturbances of iron metabolism and distribution, which appear to be independent of the diet in terms of competition between elements in intestinal absorption, as the phenomenon also affected rats receiving the standard, unsupplemented diet. The primary factor initiating or modifying iron metabolism and distribution appears to be cancer. This is confirmed not only by the analysis performed within individual groups) (control vs. cancer on a given diet) but also by the comparison of cancer groups with control groups, independently of the diet used (Table IV). Why is this, and what mechanisms are involved? Iron plays a very important role in the body, transporting oxygen and influencing cell growth, proliferation, and replication, as it is a component of the beta subunit of the enzyme ribonucleotide reductase $(32,33)$. However, this element, due to its incomplete electronic structure, can catalyse numerous electron transfer reactions, such as the Fenton reaction, which results in a hydroxyl radical, one of the most reactive oxidants. Iron can exacerbate oxidative stress and lead to the generation of reactive oxygen species (ROS) (32).

The hydroxyl radicals produced lead to the formation of 8-oxo-7,8-dihydro-2'-deoxyguanosine (8-oxo-dG), which can cause point mutations in DNA and is regarded as an indicator of oxidative stress and a biomarker of cancer risk $(33,34)$. Another possible model of the dependence of carcinogenesis on iron is the effect of oxidative stress induced by this element on the activity of signalling pathways affecting apoptosis $(21,22,35)$.

However, the role of iron in the context of oxidative stress is not alone in the pathogenesis of cancer. Although normal and cancer cells have similar Fe requirements, uncontrolled proliferation of the latter increases the demand for this element $(18-20)$. It has been demonstrated that the more aggressive a tumour is, the more transferrin receptors it has on the surface of its cells. Breast cancer cells have been shown to have 5 to 15 times more of these receptors than healthy cells $(36,37)$.

Another possibility is interaction of iron with metabolism of oestrogen, a known risk factor for breast cancer. An intermediate product of the redox reaction in oestrogen metabolism is semiquinone, a free radical that can react with $\mathrm{O}_{2}$ and form superoxide radicals. They can reduce $\mathrm{Fe}^{3+}$ ions bound to ferritin to $\mathrm{Fe}^{2+}$, resulting in the release of stored iron reserves $(38,39)$. Iron can also exert a carcinogenic effect through unfavourable replacement of zinc in zinc finger proteins, i.e. with the protein domain stabilized by $\mathrm{Zn}^{2+}$ ions. These play a crucial role in DNA replication and transcription. Replacement of the antioxidant zinc with an iron atom may result in free radical generation and damage to the genetic material (40). In our study, it should be emphasized that characteristic changes in the distribution of elements were frequently observed in the case of iron.

It seems very likely that the development and progression of cancer is linked to iron content in cells and its increased accumulation in tumour tissue (at the expense of other iron storage tissues). In this context, it seems reasonable to search for compounds chelating iron and potentially reducing the reserves of this element available to cancer tissue $(35,36)$. Iron chelators are natural or synthetic small molecules that bind iron with a high affinity.

Many in vivo and in vitro studies have shown that ironchelating compounds have an antineoplastic effect and are even being considered for use in oncological treatment (41$43)$. Synthetic iron chelators taken into account as potential antineoplastic agents include deferasirox (41), ciclopirox (42). It is worth noting that natural plant-derived compounds are also under consideration, such as curcumin (and its synthetic derivatives) (43). 
In the present study, supplementation of rat diets with a combination of two antioxidants, zinc and genistein, was the only treatment that produced no changes in iron distribution in the tissues and fluids (in contrast with combined supplementation with zinc and the other polyphenol, i.e. resveratrol). Unfortunately, this did not translate into a chemopreventive effect $(27,30)$, but the dosage of genistein $(0.2$ $\mathrm{mg} / \mathrm{kg}$ body) may have been too small, as it was extrapolated for rats from the average (low) dietary intake of genistein in humans in western countries. Hsieh et al. (44) observed that genistein had different effects depending on the dosage in an in vitro study on the effect of this compound on proliferation of MCF-7 breast cancer cells with ESR expression (dose $>10 \mu \mathrm{M}$ - antiproliferative effect, doses up to $1.0 \mu \mathrm{M}$ - stimulation of proliferation). Research on animals has also shown the proliferative activity of this isoflavone to be dependent on the dose of genistein and on the oestradiol concentration in the body (45). Genistein administered to rats before sexual maturity has been shown to protect against tumour development, whereas in analyses involving older animals this effect is less evident (45).

In summary, several reports have given evidence that alterations in the import, export and storage of cellular iron may contribute to breast cancer development, behavior and recurrence. In light of the presented investigations it seems particularly reasonable to look for ways of blocking access of neoplastic cells to the body iron stores. In the present study, irrespective of the diet used (except for the diet supplemented with zinc and genistein), chemical induction of mammary carcinoma induced changes in iron distribution, probably to the growing tumour. This effect was not observed in the case of the diet supplemented with zinc in combination with genistein, which may indicate that this polyphenol affects iron metabolism and may reduce the availability of this element to cancer tissue. However, this idea requires further research, particularly involving the application of other doses of these compounds.

\section{Conflicts of Interest}

The Authors have no potential conflicts of interest.

\section{Authors' Contributions}

DS and BBK designed the experiments, performed experiments, analyzed data and wrote the paper; JM gave technical support and conceptual advice; AT revised the manuscript.

\section{References}

1 Bray F, Ferlay J, Soerjomataram I, Siegel RL, Torre LA and Jemal A: Global cancer statistics 2018: GLOBOCAN estimates of incidence and mortality worldwide for 36 cancers in 185 countries. CA Cancer J Clin 68: 394-424, 2018. PMID: 30207593. DOI: $10.3322 /$ caac. 21492

2 Alam S and Kelleher SL: Cellular mechanisms of zinc dysregulation: a perspective on zinc homeostasis as an etiological factor in the development and progression of breast cancer. Nutrients 4: 875-903, 2012. PMID: 23016122. DOI: 10.3390/nu4080875

3 Skrovanek S, DiGuilio K, Bailey R, Huntington W, Urbas R, Mayilvaganan B, Mercogliano $G$ and Mullin JM: Zinc and gastrointestinal disease. World J Gastrointest Pathophysiol 5: 496-513, 2014. PMID: 25400994. DOI: 10.4291/wjgp.v5.i4.496

4 Maywald M, Wessels I and Rink L: Zinc Signals and Immunity. Int J Mol Sci 18, 2017. PMID: 29064429. DOI: 10.3390/ ijms 18102222

5 Suzuki M, Endo M, Shinohara F, Echigo S and Rikiishi H: Differential apoptotic response of human cancer cells to organoselenium compounds. Cancer Chemother Pharmacol 66: 475484, 2010. PMID: 19940991. DOI: 10.1007/s00280-009-1183-6

6 Cai X, Wang C, Yu W, Fan W, Wang S, Shen N, Wu P, Li X and Wang F: Selenium exposure and cancer risk: an updated metaanalysis and meta-regression. Sci Rep 6: 19213, 2016. PMID: 26786590. DOI: 10.1038/srep19213.

7 Sinha D, Sarkar N, Biswas J and Bishayee A: Resveratrol for breast cancer prevention and therapy: Preclinical evidence and molecular mechanisms. Semin Cancer Biol 40-41: 209-232, 2016. PMID: 26774195. DOI: 10.1016/j.semcancer.2015.11.001

8 Spagnuolo C, Russo GL, Orhan IE, Habtemariam S, Daglia M, Sureda A, Nabavi SF, Devi KP, Loizzo MR, Tundis R and Nabavi SM: Genistein and cancer: current status, challenges, and future directions. Adv Nutr 6: 408-419, 2015. PMID: 26178025. DOI: 10.3945/an.114.008052

9 Barrajón-Catalán E: Natural compounds as new cancer treatments. Medicines 6: 78, 2019. PMID: 31340520. DOI: 10.3390/medicines6030078

10 Skrajnowska D and Bobrowska-Korczak B: Role of zinc in immune system and anti-cancer defense mechanisms. Nutrients 11, 2019. PMID: 31546724. DOI: 10.3390/nu11102273

11 Wessels I, Maywald M and Rink L: Zinc as a gatekeeper of immune function. Nutrients 9, 2017. PMID: 29186856. DOI: 10.3390/nu9121286

12 Hashemi S-M, Sadeghi M, Vahedi Tabas A, Bouya S, Danesh HA, Khazaei A and Allahyari A: Serum levels of selenium and zinc in patients with breast cancer: A case-control study. Int J Cancer Manag 10(12): e11463, 2017. DOI: 10.5812/ijcm.11463

13 Singh CK, George J and Ahmad N: Resveratrol-based combinatorial strategies for cancer management. Ann NY Acad Sci 1290: 113-121, 2013. PMID: 23855473. DOI: 10.1111/nyas.12160

14 Li Y, Ellis K-L, Ali S, El-Rayes BF, Nedeljkovic-Kurepa A, Kucuk O, Philip PA and Sarkar FH: Apoptosis-inducing effect of chemotherapeutic agents is potentiated by soy isoflavone genistein, a natural inhibitor of NF-kappaB in BxPC-3 pancreatic cancer cell line. Pancreas 28: e90-95, 2004. PMID: 15097869. DOI: 10.1097/00006676-200405000-00020

15 Li Y, Ahmed F, Ali S, Philip PA, Kucuk O and Sarkar FH: Inactivation of nuclear factor kappaB by soy isoflavone genistein contributes to increased apoptosis induced by chemotherapeutic agents in human cancer cells. Cancer Res 65: 6934-6942, 2005. PMID: 16061678. DOI: 10.1158/0008-5472.CAN-04-4604

16 Mohammad RM, Al-Katib A, Aboukameel A, Doerge DR, Sarkar F and Kucuk O: Genistein sensitizes diffuse large cell lymphoma to CHOP (cyclophosphamide, doxorubicin, vincristine, prednisone) chemotherapy. Mol Cancer Ther 2: 1361-1368, 2003. PMID: 14707277.

17 El-Rayes BF, Ali S, Ali IF, Philip PA, Abbruzzese J and Sarkar FH: Potentiation of the effect of erlotinib by genistein in 
pancreatic cancer: The role of Akt and Nuclear Factor-kB. Cancer Res 66: 10553-10559, 2006. PMID: 17079479. DOI: 10.1158/0008-5472.CAN-06-2333

18 Naidu BG, Srikanth S, Raju GJN and Sarita P: PIXE analysis of blood serum of breast cancer patients undergoing successive chemotherapy. J Radioanal Nucl Chem 323: 1307-1316, 2020. DOI: $10.1007 / \mathrm{s} 10967-019-06988-7$

19 Pasha Q, Malik SA, Iqbal J, Shaheen N and Shah MH: Comparative evaluation of trace metal distribution and correlation in human malignant and benign breast tissues. Biol Trace Elem Res 125: 3040, 2008. PMID: 18496653. DOI: 10.1007/s12011-008-8158-Z

20 Al-Ebraheem A, Farquharson MJ and Ryan E: The evaluation of biologically important trace metals in liver, kidney and breast tissue. Appl Radiat Isot 67: 470-474, 2009. PMID: 18675548. DOI: $10.1016 /$ j.apradiso.2008.06.018

21 Torti SV and Torti FM: Iron and cancer: more ore to be mined. Nat Rev Cancer 13: 342-355, 2013. PMID: 23594855. DOI: $10.1038 / \mathrm{nrc} 3495$

22 Marques O, da Silva BM, Porto G and Lopes C: Iron homeostasis in breast cancer. Cancer Lett 347: 1-14, 2014. PMID: 24486738. DOI: 10.1016/j.canlet.2014.01.029

23 Pastuszewska B, Ochtabińska A and Morawski A: A note on the nutritional adequacy of stock diets for laboratory rats and mice. $\mathrm{J}$ Anim Feed Sci 9: 533-542, 2000. DOI: 10.22358/jafs/68075/2000

24 Bobrowska-Korczak B, Skrajnowska D and Tokarz A: The effect of dietary zinc - and polyphenols intake on DMBA-induced mammary tumorigenesis in rats. J Biomed Sci 19: 43, 2012. PMID: 22507225. DOI: 10.1186/1423-0127-19-43

25 Skrajnowska D, Korczak BB-, Tokarz A, Kazimierczuk A, Klepacz M, Makowska J and Gadzinski B: The effect of zinc and phytoestrogen supplementation on the changes in mineral content of the femur of rats with chemically induced mammary carcinogenesis. J Trace Elem Med Biol Organ Soc Miner Trace Elem GMS 32: 7985, 2015. PMID: 26302916. DOI: 10.1016/j.jtemb.2015.06.004

26 National Research Council (US) Subcommittee on Laboratory Animal Nutrition: Nutrient Requirements of Laboratory Animals: Fourth Revised Edition, 1995. Washington (DC), National Academies Press (US), 1995.

27 Tyszka-Czochara M, Grzywacz A, Gdula-Argasińska J, Librowski T, Wiliński B and Opoka W: The role of zinc in the pathogenesis and treatment of central nervous system (CNS) diseases. Implications of zinc homeostasis for proper CNS function. Acta Pol Pharm 71: 369-377, 2014. PMID: 25265815.

28 Yamaguchi M, Igarashi A, Sakai M, Degawa H and Ozawa Y: Prolonged intake of dietary fermented isoflavone-rich soybean reinforced with zinc affects circulating bone biochemical markers in aged individuals. J Health Sci 51: 191-196, 2005. DOI: $10.1248 /$ jhs. .51 .191

29 Zhang JJ, Wu M, Schoene NW, Cheng W-H, Wang TTY, Alshatwi AA, Alsaif M and Lei KY: Effect of resveratrol and zinc on intracellular zinc status in normal human prostate epithelial cells. Am J Physiol Cell Physiol 297: C632-644, 2009. PMID: 19553565. DOI: 10.1152/ajpcell.00139.2009

30 Eide DJ: Zinc transporters and the cellular trafficking of zinc. Biochim Biophys Acta 1763: 711-722, 2006. PMID: 16675045. DOI: $10.1016 /$ j.bbamcr.2006.03.005

31 Gibson JN, Jellen LC, Unger EL, Morahan G, Mehta M, Earley CJ, Allen RP, Lu L and Jones BC: Genetic analysis of irondeficiency effects on the mouse spleen. Mamm Genome 22: 556562, 2011. PMID: 21732193. DOI: 10.1007/s00335-011-9344-4
32 Jomova $\mathrm{K}$ and Valko M: Advances in metal-induced oxidative stress and human disease. Toxicology 283: 65-87, 2011. PMID: 21414382. DOI: $10.1016 /$ j.tox.2011.03.001

33 Dziaman T, Jurgowiak M and Oliński R: Association between body iron stores and level of oxidatively modified DNA bases. BioTechnologia 92: 159-165, 2014. DOI: 10.5114/bta.2011.46531

34 Suzuki $\mathrm{T}$ and Kamiya H: Mutations induced by 8 -hydroxyguanine (8-oxo-7,8-dihydroguanine), a representative oxidized base, in mammalian cells. Genes Environ 39, 2016. PMID: 27980700. DOI: 10.1186/s41021-016-0051-y

35 Xue X and Shah YM: Intestinal iron homeostasis and colon tumorigenesis. Nutrients 5: 2333-2351, 2013. PMID: 23812305. DOI: 10.3390/nu5072333

36 Alkhateeb AA, Han B and Connor JR: Ferritin stimulates breast cancer cells through an iron-independent mechanism and is localized within tumor-associated macrophages. Breast Cancer Res Treat 137: 733-744, 2013. PMID: 23306463. DOI: 10.1007/s10549-012-2405-x

37 Shpyleva SI, Tryndyak VP, Kovalchuk O, Starlard-Davenport A, Chekhun VF, Beland FA and Pogribny IP: Role of ferritin alterations in human breast cancer cells. Breast Cancer Res Treat 126: 63-71, 2011. PMID: 20390345. DOI: 10.1007/s10549-0100849-4

38 Chang VC, Cotterchio M and Khoo E: Iron intake, body iron status, and risk of breast cancer: a systematic review and meta-analysis. BMC Cancer 19: 543, 2019. DOI: 10.1186/s12885-019-5642-0

39 Huang X: Does iron have a role in breast cancer? Lancet Oncol 9: 803-807, 2008. PMID: 18672216. DOI: 10.1016/S14702045(08)70200-6

40 Kabat GC and Rohan TE: Does excess iron play a role in breast carcinogenesis? An unresolved hypothesis. Cancer Causes Control CCC 18: 1047-1053, 2007. PMID: 17823849. DOI: 10.1007/s10552-007-9058-9

41 Lui GYL, Obeidy P, Ford SJ, Tselepis C, Sharp DM, Jansson PJ, Kalinowski DS, Kovacevic Z, Lovejoy DB and Richardson DR: The iron chelator, deferasirox, as a novel strategy for cancer treatment: oral activity against human lung tumor xenografts and molecular mechanism of action. Mol Pharmacol 83: 179-190, 2013. PMID: 23074173. DOI: 10.1124/mol.112.081893

42 Zhou H, Shen T, Luo Y, Liu L, Chen W, Xu B, Han X, Pang J, Rivera CA and Huang S: The antitumor activity of the fungicide ciclopirox. Int J Cancer 127: 2467-2477, 2010. PMID: 20225320. DOI: $10.1002 /$ ijc. 25255

43 Panda AK, Chakraborty D, Sarkar I, Khan T and Sa G: New insights into therapeutic activity and anticancer properties of curcumin. J Exp Pharmacol 9: 31-45, 2017. PMID: 28435333. DOI: $10.2147 /$ JEP.S70568

44 Hsieh C-Y, Santell RC, Haslam SZ and Helferich WG: Estrogenic effects of genistein on the growth of estrogen receptor-positive human breast cancer (MCF-7) cells in vitro and in vivo. Cancer Res 58: 3833-3838, 1998. PMID: 9731492.

45 Pei R-J, Sato M, Yuri T, Danbara N, Nikaido Y and Tsubura A: Effect of prenatal and prepubertal genistein exposure on $\mathrm{N}$ methyl-N-nitrosourea-induced mammary tumorigenesis in female Sprague-Dawley rats. In Vivo 17: 349-357, 2003. PMID: 12929590.

Received September 28, 2020

Revised October 19, 2020

Accepted October 20, 2020 